\title{
Experimental Study on Bending Moment of Double-Row Steel Pipe Piles in Foundation Excavation
}

\author{
Ming-yi Zhang, ${ }^{1,2}$ Jia-xiao Ma, ${ }^{1}$ Shu-juan Yang, ${ }^{1,2}$ Yong-hong Wang $\mathbb{D}^{1,2}$ Xiao-yu Bai, ${ }^{1,2}$ \\ and Shao-xia Sun ${ }^{1}$ \\ ${ }^{1}$ Department of Civil Engineering, Qingdao University of Technology, Qingdao, China \\ ${ }^{2}$ Cooperative Innovation Center of Engineering Construction and Safety in Shandong Blue Economic Zone, Qingdao, China \\ Correspondence should be addressed to Yong-hong Wang; wangyonghong@qut.edu.cn
}

Received 5 August 2020; Revised 26 September 2020; Accepted 12 October 2020; Published 26 October 2020

Academic Editor: bingxiang yuan

Copyright ( $\odot 2020$ Ming-yi Zhang et al. This is an open access article distributed under the Creative Commons Attribution License, which permits unrestricted use, distribution, and reproduction in any medium, provided the original work is properly cited.

Double-row steel pipe piles have been widely used in retaining and protection of foundation excavation because of the advantages of high bearing capacity, high flexural rigidity, fast construction speed, and so on. This study presents a field test to assess the feasibility of strain gauges in monitoring the strain of double-row steel pipe piles during foundation excavation. Two steel pipe piles were instrumented with strain gauges and then installed into the drilling holes. The installation method of strain gauges is introduced first. Then, the bending moment of the test piles during the foundation excavation was analyzed. The field test results indicate that the survival rate of strain gauges was $100 \%$, and the monitoring method used in the test was feasible to measure the bending moment of double-row steel pipe piles. Moreover, with the increase in foundation excavation depth, the bending moment of the test piles all increased, and the bending moment of the inner pile was obviously higher than that of the outer pile. The bending moment distribution of the whole support system accords with the conventional pile-anchor mode. The test results can provide reference and basis for the design and construction of double-row steel pipe piles.

\section{Introduction}

With the rapid development of high-rise buildings and underground structures, the scale of underground projects was increasing, and the design and construction of deep pit support was becoming more and more important [1-3]. How to ensure the stability of the deep pit, control the deformation of the pit support structure, and reduce the impact on the surrounding environment has become a research hotspot [4-7].

The double-row steel pipe pile is a kind of spatial composite support structure, which is composed of two rows of reinforced steel pipe piles and rigid connected top beams [8]. The bearing capacity of this support structure is good, and the deformation of the foundation pit can be controlled well $[9,10]$. Moreover, the double-row steel pipe pile has a good applicability for foundation pit support engineering [11]. In order to improve the bearing capacity, optimize the design, and guide the construction of this support structure, many scholars have studied the mechanical characteristics of the steel pipe pile.

Liu and $\mathrm{Fu}$ [12] established a finite element model of the planar bar system of double-row piles considering the pilesoil effect and studied the key parameters and soil pressure distribution of the finite element model of double-row piles. Bai et al. [13] established a calculation model of double-row pile support structure in the deep foundation pit considering the spatial effect and analyzed the influence of the top beam on the bearing capacity of double-row pile structure. Huang et al. [14] divided the support structure of double-row piles into two parts and established the flexural differential equation of the piles. Shi and Gong. [15] used finite element software to simulate the excavation process of the deep foundation pit supported by double-row piles and studied the mechanical characteristics of double-row piles. Wang et al. [16] used MIDAS/GTS simulation software to study the stress and deformation state of double-row piles. Most of the previous studies have 
TABLe 1: Physical and mechanical properties of subsoil.

\begin{tabular}{lcccccc}
\hline Layer number & Name of soil layer & $h(\mathrm{~m})$ & $\rho\left(\mathrm{g} \cdot \mathrm{cm}^{-3}\right)$ & $\varphi\left(^{\circ}\right)$ & $\gamma\left(\mathrm{kN} \cdot \mathrm{m}^{-3}\right)$ & $c(\mathrm{kPa})$ \\
\hline 1 & Fill & 1.8 & 1.8 & 15.0 & 18.0 \\
2 & Silty clay & 1.4 & 2.0 & 20.0 & 20.0 & 20.0 \\
3 & Coarse sand & 2.5 & 2.0 & 35.0 & 20.5 & 7.0 \\
4 & Granite & 0.5 & 2.5 & 50.0 & 25.0 & 6.0 \\
5 & Lamprophyre & 2.8 & 2.4 & 42.0 & 24.0 & 26.5 \\
6 & Cataclasite & 15.2 & 2.6 & 55.0 & 6.0 \\
7 & Granite & 16.5 & 2.6 & 65.0 & 26.0 \\
\hline
\end{tabular}

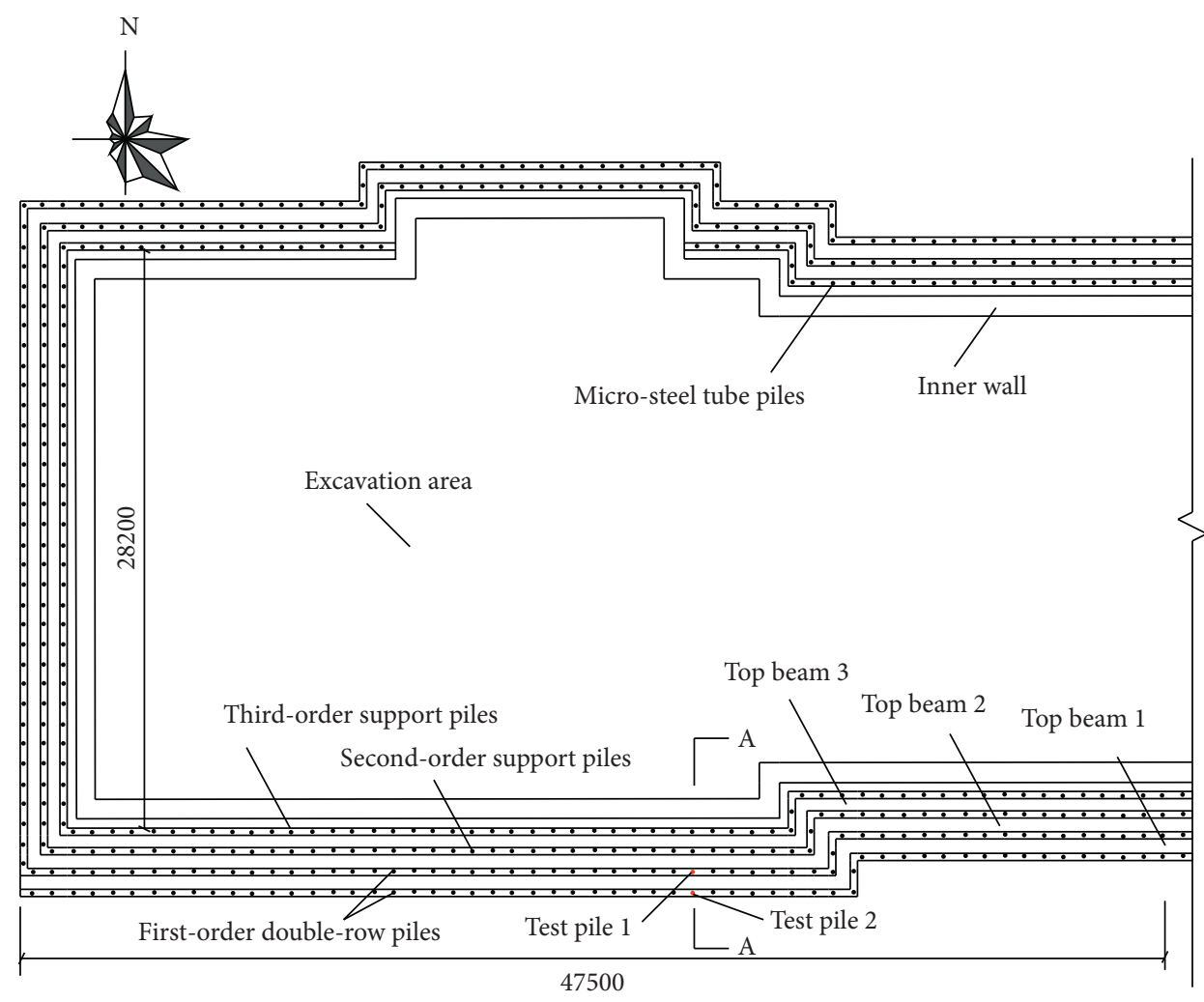

Figure 1: Plan of the foundation pit.

investigated the mechanical characteristics of double-row piles through theoretical calculation $[12,17]$ and numerical simulation [18-20], and some scholars studied the stress characteristics of double-row piles through the laboratory model test $[21,22]$. However, due to the complexity of the construction site, theoretical calculation and numerical simulation values cannot fully reflect the real stress characteristics of the double-row piles, and the measured values from field tests are more realistic $[23,24]$.

Studies on the mechanical characteristics of double-row steel pipe piles in foundation excavation through the field test are rarely reported, and few relevant research studies can be found, especially in the field of long-term monitoring of double-row steel pipe piles. In this paper, the strain gauges were installed on the surface of double-row steel pipe piles to monitor the strain of piles in foundation excavation and studied the feasibility of the installation method of gauges used in the test. Moreover, the bending moment of doublerow steel pipe piles during the foundation excavation was analyzed.

\section{Site Conditions and Test Program}

2.1. Site Condition. The site is a typical soil-rock combination of top soil and bottom rock, and the soil layer distribution from top to bottom is plain fill, powdered clay, coarse sand, strong sand, strong clay, weathered granite, strongly weathered dunite porphyry, massive fractured rocks, and slightly weathered granite, respectively. The stable elevation of the ground water level in the field is $15.85 \sim 20.33 \mathrm{~m}$, the buried depth of the stable water level is $2.20 \sim 4.30 \mathrm{~m}$, and the underground water level in the test site is $15.99 \mathrm{~m}$. The physical and mechanical parameters of each layer are shown in Table 1.

2.2. Support Structure. This project is a transfer station of a subway, and the plan of the foundation pit is shown in Figure 1. The construction method is an open-cut method and smooth practice. The foundation pit adopts the microsteel pipe pile advance support system, which 


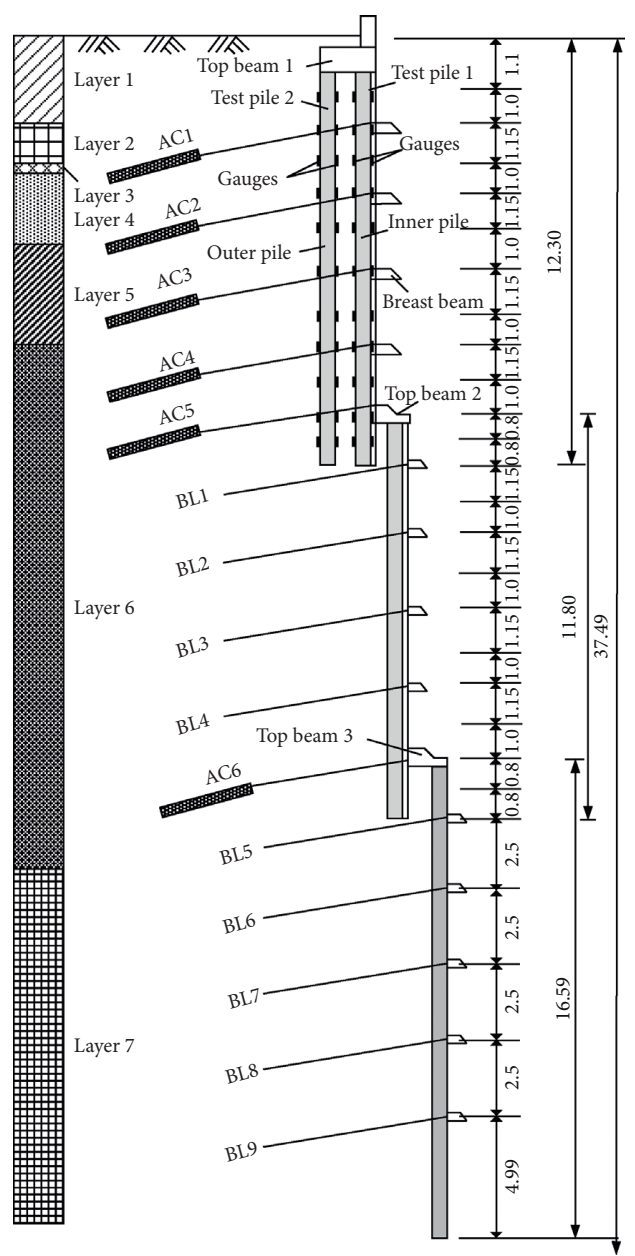

(a)

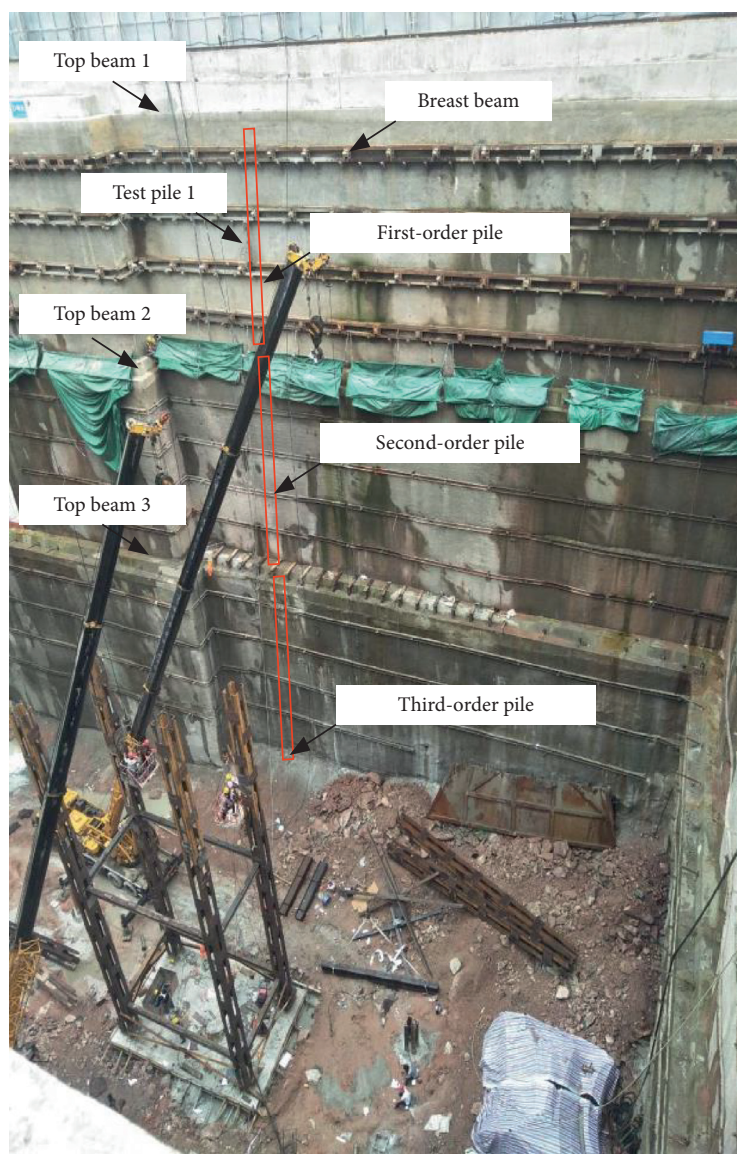

(b)

Figure 2: The profile A-A and scene picture of the foundation pit.

has three steps from top to bottom. The first-order support structure used double-row steel pipe piles with the external diameter of $168 \mathrm{~mm}$, wall thickness of $8 \mathrm{~mm}$, and pile length of $12.3 \mathrm{~m}$. The horizontal spacing of steel pipe piles was $1 \mathrm{~m}$, and the steel pipe piles were embedded in the rock strata $1.5 \mathrm{~m}$. The top of the doublerow steel piles was connected by a reinforced concrete crown beam with a width of $1000 \mathrm{~mm}$ and a height of $400 \mathrm{~mm}$. The second-order and third-order support structures adopted single-row steel pipe piles with the length of $11.8 \mathrm{~m}$ and $16.6 \mathrm{~m}$, respectively, and the diameter and wall thickness of the piles are the same as those of the double-row steel pipe piles. In order to improve the stability of the support structure, the prestressed anchor cable combined support was adopted in the soil layer, numbered AC1 AC6, and the bolt combined support with HRB400 steel was adopted in the rock layer, numbered BL1 BL9.

2.3. Test Program. Eleven pairs of strain gauges were installed on the surface of one steel tube pile, which were marked as $\mathrm{A} 1 \sim \mathrm{A} 11$ and $\mathrm{A} 1^{\prime} \sim \mathrm{A} 11^{\prime}$, respectively, from the top to the pile tip. The strain gauges were used to monitor the strain state of the pile at different positions under different working conditions. The profile A-A and sensors installation location are shown in Figure 2. The installation steps of strain gauge are as follows: (1) Mark the installation positions of strain gauges with a pen, and drill a hole with a diameter of $20 \mathrm{~mm}$ next to each installation position for threading (Figure 3(a)). (2) The sandpaper was used to polish the installation position. After wiping the polishing place with alcohol, 502 glue was used to paste the strain gauge on the surface of the steel pipe pile. Then, the ohmmeter was used to test the survival rate of the strain gauges (Figure 3(b)). (3) In order to improve the survival rate of the strain gauges during the test, the strain gauges were coated with 704 adhesive and epoxy resin, respectively (Figure 3(c)). (4) The strain gauge line was connected with the data line, and the data line was inserted into the pile through the hole next to the installation position of the gauge. In order to protect the data line during pile driving, insert the data line into the plastic hose and fix the data line on the pile top (Figure 3(d)).

The mechanical drilling method was adopted, and the diameter of the drilling is $200 \mathrm{~mm}$, as shown in Figure 4(a). 


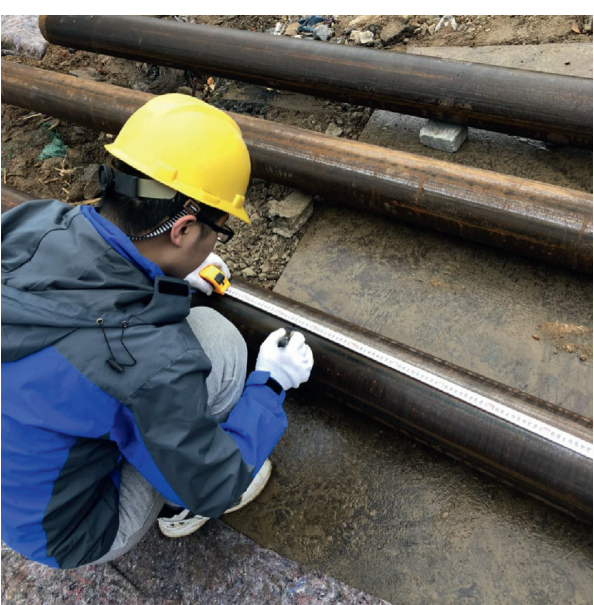

(a)

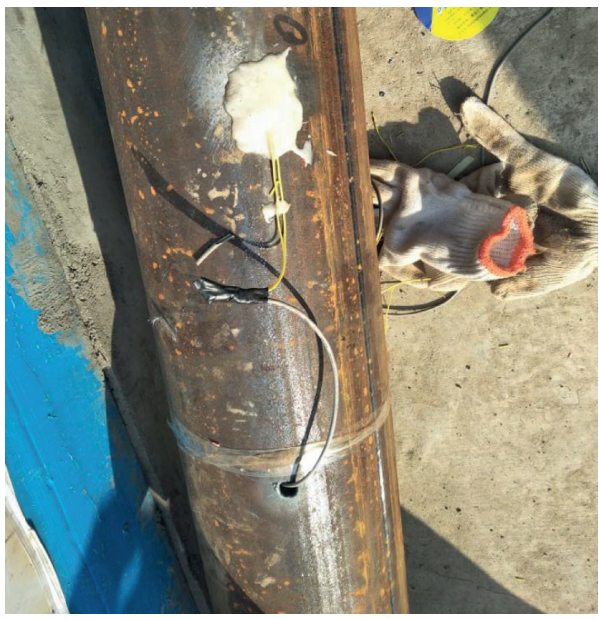

(c)

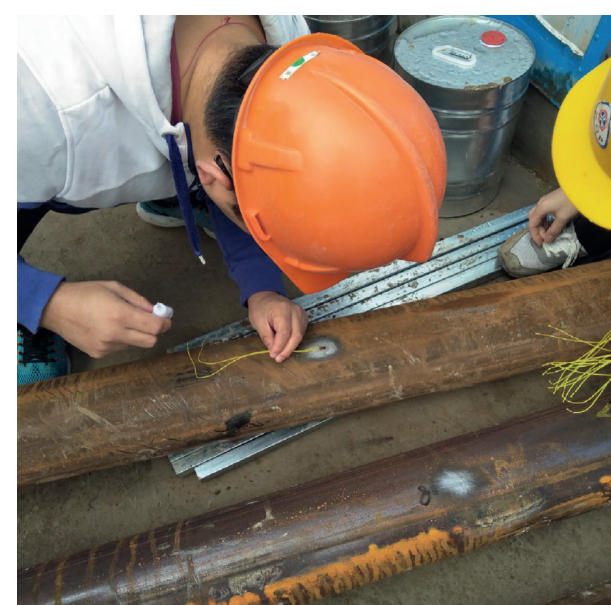

(b)

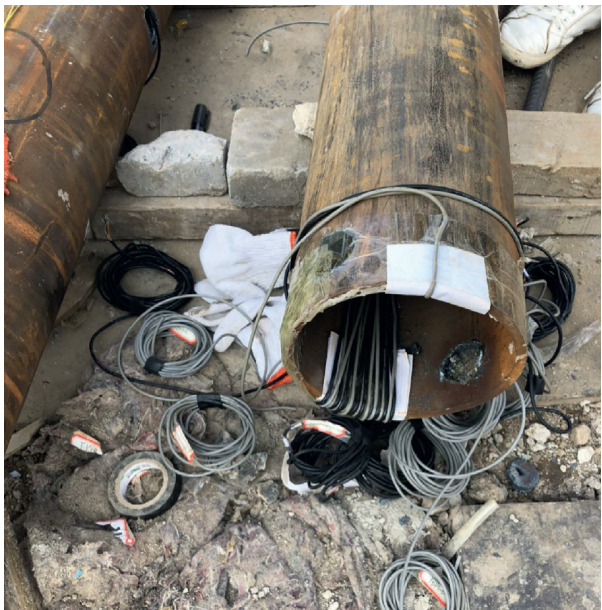

(d)

FIgURE 3: Schematic diagram of sensor installation process. (a) Installation location marking. (b) Strain gauge sticking. (c) Strain gauge protection. (d) Data lines fixation.

The test steel pipe piles were put into the drilling holes, and the test piles were slowly pressed to the designed elevation (Figure 4(b)). After that, the grouting pipe was inserted into the bottom of the micro-steel pipe pile, and the cement paste was injected into the piles. The water-cement ratio of the cement paste was 0.5 , and the grouting pressure is $0.5 \mathrm{MPa}$. The DH3816N dynamic strain acquisition instrument was used to monitor the strain change of the strain gauges on the pile body under different working conditions. The bending moment value of the pile body can be calculated through the measured strain value of the gauges. The monitoring date and working conditions are shown in Table 2. The monitoring date is the number of days from the first data collection.

\section{Results and Discussion}

3.1. Bending Moment of Piles during the First-Order Excavation. Bending moment of the test piles during the first-order excavation is shown in Figures 5(a) and 5(b). With the excavation of the foundation pit, the bending moment of test pile 1 increased gradually, and there are many points of contraflexure, which was consistent with the results of Liu and $\mathrm{Fu}$ [12] and Bai et al. [13]. The bending moment at the pile top increased with the excavation depth. At the beginning of excavation, the bending moment of the lower section of the pile was small. When the foundation pit was excavated to $10.75 \mathrm{~m}$, the bending moment at the pile top reached the maximum of $15 \mathrm{kN} \cdot \mathrm{m}$. This indicates that in the process of foundation pit excavation, the upper section of the steel pipe pile played the support role first and bore a large load, according to the literature $[8,10]$. At beginning of excavation, the deep section of the pile can be regarded as the fixed end due to its large buried depth and embedment in the soil and rock, which has borne a small load [23].

It can be obviously seen that both positive and negative bending moments exist on the pile, which was consistent with the results of Shi and Gong. [15] The bending moment at $4.30 \sim 6.45 \mathrm{~m}$ of the pile was negative, indicating that the soil surface of the pile was under tension, and the extreme value of negative bending moment at measuring section A5-A5' was $-13.01 \mathrm{kN} \cdot \mathrm{m}$. The bending moment at $6.45 \sim 8.60 \mathrm{~m}$ of the pile was positive, indicating the foundation pit surface of the pile was under tension, and the extreme value of positive bending moment at measuring section A7-A7' was $11.44 \mathrm{kN} \cdot \mathrm{m}$. 


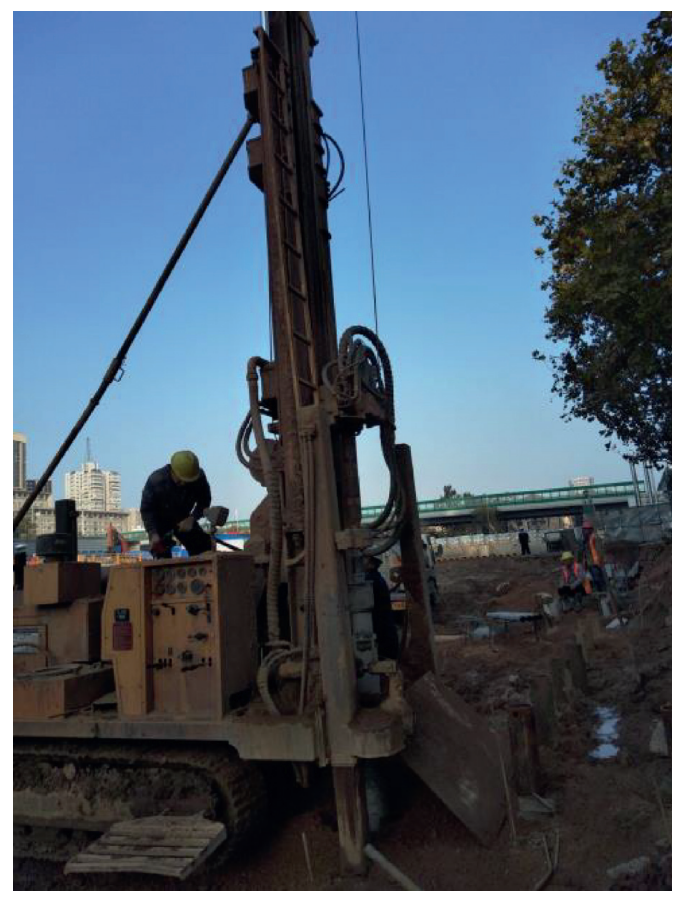

(a)

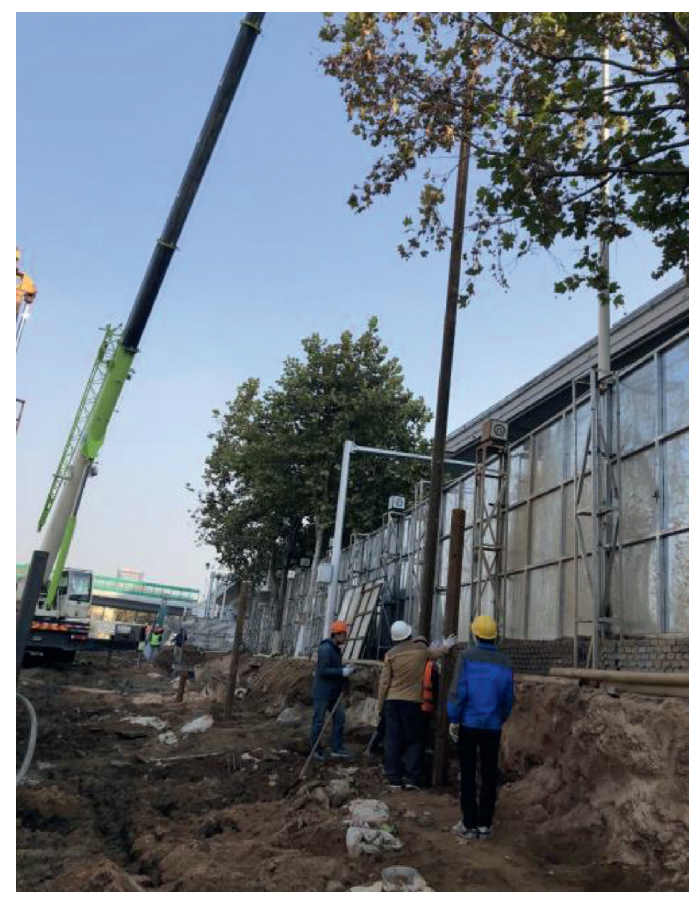

(b)

Figure 4: Schematic diagram of test pile installation process. (a) Drilling the holes. (b) Test pile lifting.

TABLE 2: Monitoring date and working conditions.

\begin{tabular}{lc}
\hline Monitoring date $(\mathrm{d})$ & Working conditions \\
\hline 1 & Depth is 0 \\
22 & Depth is $2.35 \mathrm{~m}$ \\
27 & Depth is $4.50 \mathrm{~m}, \mathrm{AC} 1 \mathrm{installation}$ \\
37 & Depth is $5.00 \mathrm{~m}, \mathrm{AC} 2$ installation \\
41 & Depth is $6.75 \mathrm{~m}$ \\
47 & AC3 installation \\
54 & Depth is $8.60 \mathrm{~m}$ \\
88 & Depth is $10.75 \mathrm{~m}$ \\
104 & Second-order piles installation \\
117 & Depth is $12.75 \mathrm{~m}$ \\
123 & Depth is $16.65 \mathrm{~m}, \mathrm{BL} 1$ installation \\
139 & Depth is $19.10 \mathrm{~m}, \mathrm{BL} 2 \mathrm{installation}$ \\
153 & Depth is $20.95 \mathrm{~m}, \mathrm{BL} 3$ installation \\
161 & Third-order piles installation \\
168 & Depth is $21.4 \mathrm{~m}$ \\
177 & Depth is $23.00 \mathrm{~m}$ \\
184 & Depth is $25.50 \mathrm{~m}, \mathrm{BL} 5$ installation \\
190 & BL6 installation \\
206 & Depth is $28.00 \mathrm{~m}$ \\
210 & Depth is $28.74 \mathrm{~m}$ \\
216 & Depth is $32.50 \mathrm{~m}$ \\
221 & BL7 and BL8 installation \\
\hline
\end{tabular}

The installation of the anchor cable had influence on the bending moment of piles. After AC2 installation, the bending moment of the 4-4' measuring section decreased from $6.82 \mathrm{kN} \cdot \mathrm{m}$ to $2.73 \mathrm{kN} \cdot \mathrm{m}$. After the installation of the third anchor cable tension, the pile bending moment at the 6-6' measuring section decreased from $7.73 \mathrm{kN} \cdot \mathrm{m}$ to $1.80 \mathrm{kN} \cdot \mathrm{m}$. When the foundation pit was excavated to $10.75 \mathrm{~m}, \mathrm{AC} 4$ and AC5 were not installed in time, and the bending moment at the bottom of the pile increased significantly. This is because the steel pipe piles can be regarded as cantilever piles when anchor cables were not installed, and the lateral earth pressure was mainly balanced by the passive earth pressure at the bottom of the pile. The installation of anchor cables was equivalent to adding spring support to the steel pipe pile, which restricted the deformation of the pile and reduced the bending moment of the pile [19].

As shown in Figure 5(b), the bending moment variation of pile 1 and pile 2 was similar. The bending moment increased with the increase in excavation depth; the point of contraflexure appeared at the anchor cable installation position of $2.15 \mathrm{~m}, 4.3 \mathrm{~m}, 6.45 \mathrm{~m}$, and $10.75 \mathrm{~m}$, respectively. Compared with the bending moment of test pile 1 , the bending moment of test pile 2 was smaller, and the maximum negative bending moment of test pile 2 was less than $10 \mathrm{kN} \cdot \mathrm{m}$, which is $70 \%$ of test pile 1 . Moreover, the bending moment at $4.30 \sim 6.45 \mathrm{~m}$ of test pile 2 was positive, and the bending moment at $6.45 \sim 8.60 \mathrm{~m}$ of test pile 2 was negative. The bending moment value of test pile 2 is positive, which was opposite to the bending moment value of test pile 1 . This is because top beam 1 and the top of test pile 1 and test pile 2 were rigidly connected; top beam 1 and the pile cannot rotate each other, so this structure can resist the bending moment together [20]. The bending moment of test pile 1 was obviously higher than that of test pile 2 due to the action of soil pressure between test piles 1 and 2, according to the literature [9].

3.2. Bending Moment of Piles during the Second-Order Excavation. Bending moment of the test piles during the first-order excavation is shown in Figures 6(a) and 6(b). 


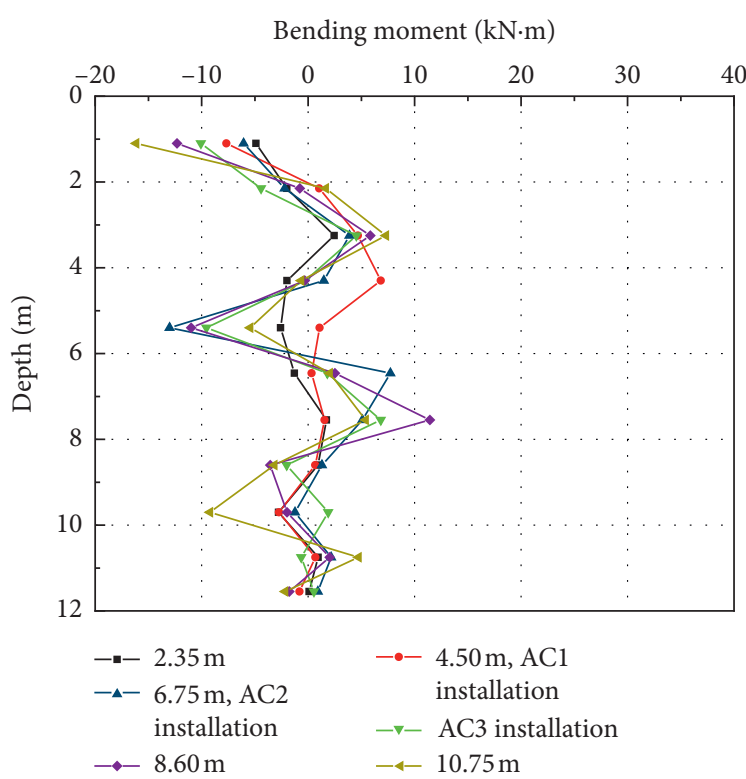

(a)

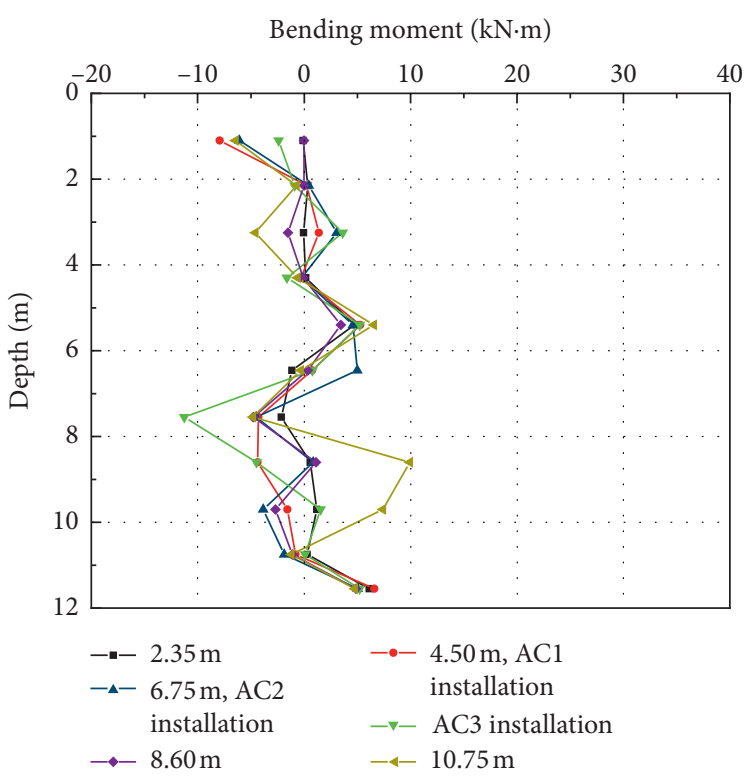

(b)

Figure 5: Bending moment of piles during the first-order excavation. (a) Test pile 1. (b) Test pile 2.

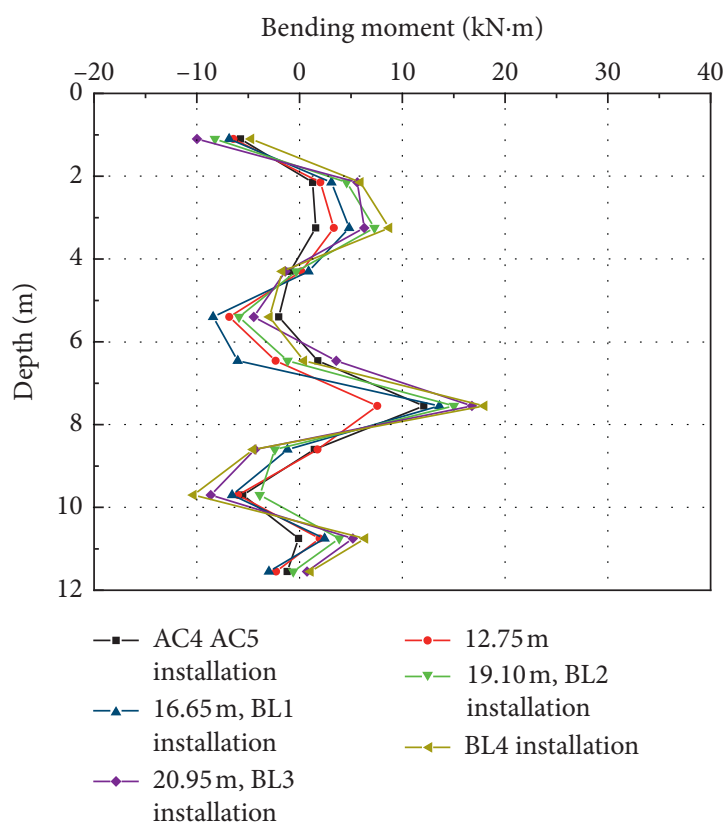

(a)

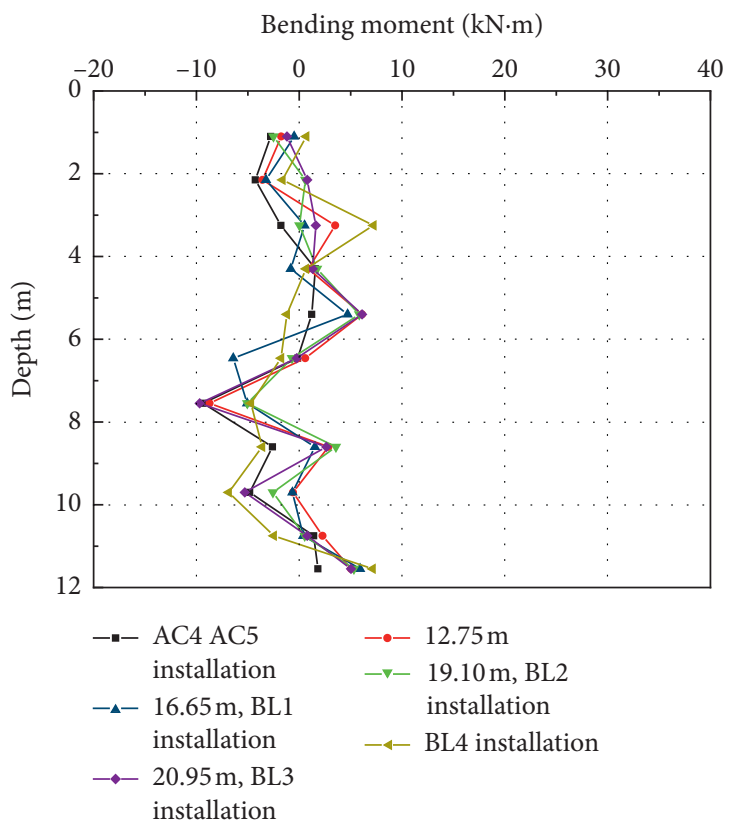

(b)

Figure 6: Bending moment of piles during the second-order excavation. (a) Test pile 1. (b) Test pile 2.

Compared with the bending moment of test pile 1 during the first-order excavation (Figure 5(a)), with the increase in excavation depth and the longer exposure time of the foundation pit, the bending moment of test pile 1 gradually increases. The bending moment of the pile increases obviously in the rock layer $(7.0 \sim 8.5 \mathrm{~m}), 7.55 \mathrm{~m}$ is the position with the maximum positive bending moment of the pile during the second-order excavation, and the maximum bending moment was $17.98 \mathrm{kN} \cdot \mathrm{m}$.
Compared with the bending moment of test pile 1 during the first-order excavation, the bending moment at the pile top was significantly reduced, and the value was between $-4.72 \sim-10 \mathrm{kN} \cdot \mathrm{m}$. The maximum negative bending moment of the pile was moved from $5.4 \mathrm{~m}$ to $9.7 \mathrm{~m}$. This indicates that the flexural rigidity of top beam 1 was high, and the composite structure of the top beam and double-row steel pipe piles was similar to rigid support [10]. Moreover, the structure can adjust the bending moment of the piles with 


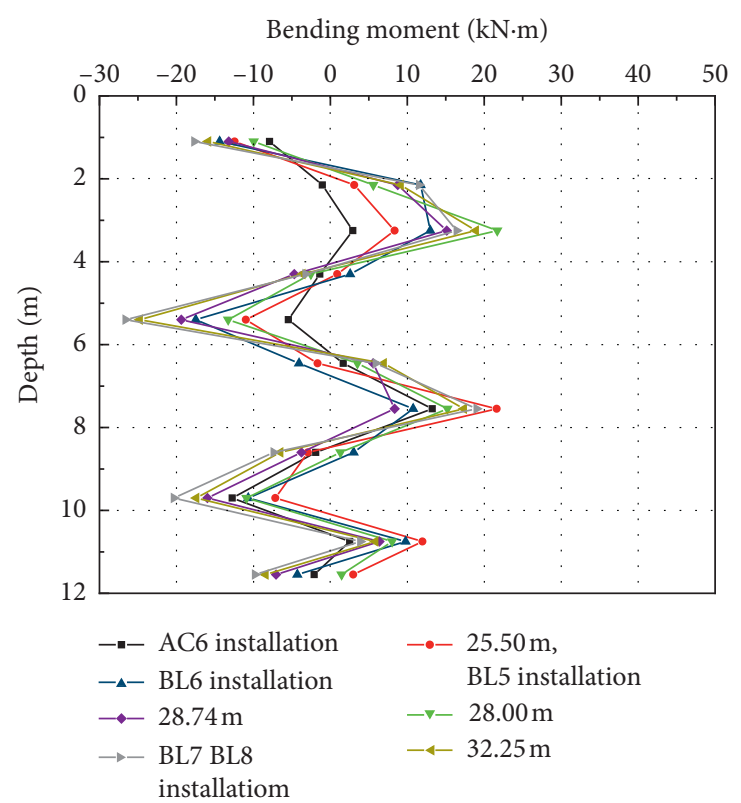

(a)

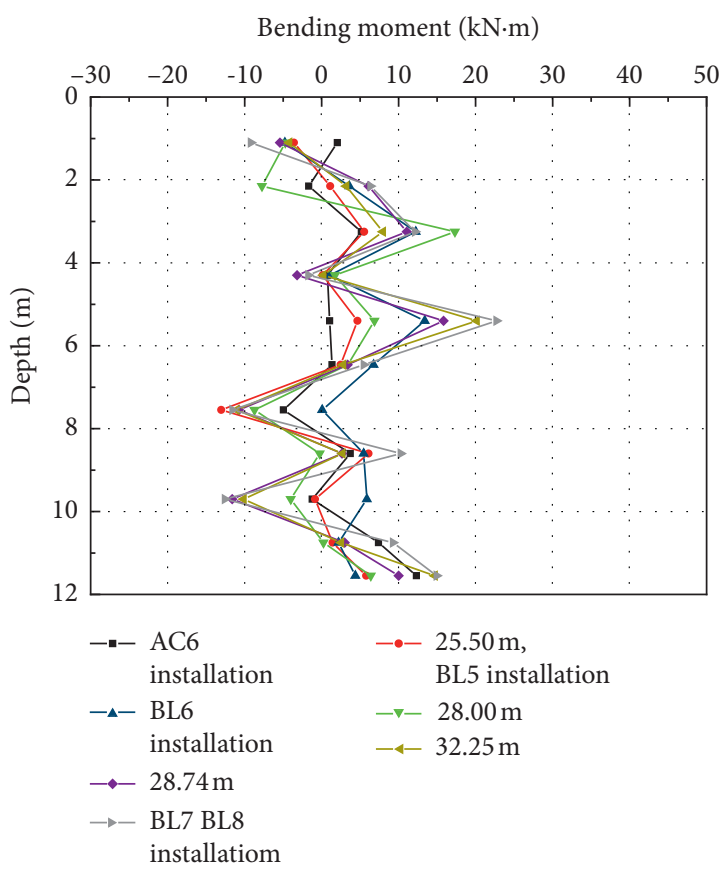

(b)

Figure 7: Bending moment of piles during the third-order excavation. (a) Test pile 1. (b) Test pile 2.

the change of the support condition of the lower end of the steel pipe pile so as to adapt to the complex and changeable load action, according to the literature [11, 19].

As shown in Figures 6(a) and 6(b), the bending moment of test pile 2 was still significantly smaller than that of test pile 1 . The maximum negative bending moment of test pile 2 was reduced from $-7.94 \mathrm{kN} \cdot \mathrm{m}$ to $-2.78 \mathrm{kN} \cdot \mathrm{m}$, which was similar to the changing trend of the bending moment of test pile 1 and consistent with the results of Zhou et al. [24] The bending moment at anchor cable position was always small, without the phenomenon of sudden increase. This is because BL1 BL4 were installed in time during the construction of the second-order excavation. The second-order support structure was the single-row steel tube pile, and the designed bearing capacity of BL1 BL4 was $210 \mathrm{kN} \sim 250 \mathrm{kN}$, which was higher than that of AC1 AC5 $(145 \mathrm{kN} \sim 202 \mathrm{kN})$. It can be seen that the timely installation of bolts and the increase in bearing capacity of bolts can effectively restrain the deformation of steel pipe piles and improve the bearing capacity of support structure [10].

\subsection{Bending Moment of Piles during the Third-Order} Excavation. As shown in Figure 7(a), with the continued excavation of the foundation pit, the bending moment of the pile increased rapidly. The maximum negative bending moment of measuring section A5-A5' reached $-26.6 \mathrm{kN} \cdot \mathrm{m}$, and the maximum positive bending moment of measuring section A5-A5' reached $19.01 \mathrm{kN} \cdot \mathrm{m}$. The positive and negative bending moments of test pile 2 also appear in the soil-rock-bound layer, which was similar to the bending moment distribution of test pile 1 . This indicates that the pile in the soil-rock layer bears a large lateral earth pressure, and the support strength of the soil- rock layer of the pile should be strengthened in the structural design of the foundation pit. After the installation of top beam 3 , the bending moment of test piles 1 and 2 was lower, indicating that the top beam can effectively limit the displacement of the steel tubular piles and improve the stability of the support structure, which was consistent with the results of Liu et al. [21] and Zhou et al. [24].

As shown in Figure 7(b), the distribution and variation of the bending moment of test pile 1 were similar to those of test pile 2; with the continued excavation of the foundation pit, the bending moment of the pile increased rapidly. However, the bending moment of test pile 2 was less than that of test pile 1 , which was similar to the bending moment during the second-order and third-order excavation.

\section{Conclusions}

The objective of this paper is to validate the feasibility of using strain gauges for monitoring the strain of double-row steel pipe piles during the foundation excavation. The installation and protection method of strain gauges was proposed. The mechanical properties of the double-row steel pipe pile were investigated. Main conclusions could be drawn as follows:

(1) The combined support form of double-row steel pipe piles combined with prestressed anchor cables was suitable for deep foundation pit support. As the main support structure, double-row steel pipe piles play an important support role in the process of foundation pit excavation.

(2) The survival rate of strain gauges was $100 \%$. The strain gauge installation method can meet the test 
requirements and can carry out long-term monitoring of the strain state of steel pipe piles at different working conditions.

(3) With the increase in foundation pit excavation depth, the bending moment of the pile increased. The bending moment distribution of the whole support system accords with the conventional pile-anchor mode.

In the future research, soil pressure sensors can be installed on the side of steel pipe piles to monitor the variation law of the lateral earth pressure during pit excavation. The displacement of the steel pipe pile can be monitored in the process of pit excavation, and the internal force change and displacement can be compared and analyzed.

\section{Data Availability}

The data used to support the findings of this study are included within the article.

\section{Conflicts of Interest}

The authors declare that they have no conflicts of interest regarding the publication of this paper.

\section{Acknowledgments}

This study was funded by the National Natural Science Foundation of China (51708316 and 51778312).

\section{References}

[1] R. J. Finno and J. F. Roboski, "Three-dimensional responses of a tied-back excavation through clay," Journal of Geotechnical and Geoenvironmental Engineering, vol. 131, no. 3, pp. 273282, 2005.

[2] B. X. Yuan, L. Xiong, L. Zhai et al., "Transparent synthetic soil and its application in modeling of soil-structure interaction using optical system," Frontiers in Earth Science, vol. 7, 276 pages, 2019.

[3] C.-Y. Ou, T.-S. Wu, and H.-S. Hsieh, "Analysis of deep excavation with column type of ground improvement in soft clay," Journal of Geotechnical Engineering, vol. 122, no. 9, pp. 709-716, 1996.

[4] B. Yuan, M. Sun, L. Xiong, Q. Luo, S. P. Pradhan, and H. Li, "Investigation of 3D deformation of transparent soil around a laterally loaded pile based on a hydraulic gradient model test," Journal of Building Engineering, vol. 28, no. 3, Article ID 101024, 2020.

[5] G. T. Kung, C. H. Juang, E. C. Hsiao, and Y. M. Hashash, "Simplified model for wall deflection and ground-surface settlement caused by braced excavation in clays," Journal of Geotechnical and Geoenvironmental Engineering, vol. 133, no. 6, pp. 731-747, 2007.

[6] L. Mu and M. Huang, "Small strain based method for predicting three-dimensional soil displacements induced by braced excavation," Tunnelling and Underground Space Technology, vol. 52, pp. 12-22, 2016.

[7] B. X. Yuan, M. Sun, Y. X. Wang, L. H. Zhai, and Q. Z. Luo, "Full 3D displacement measuring system for 3D displacement field of soil around a laterally loaded pile in transparent soil,"
International Journal of Geomechanics, vol. 19, no. 5, Article ID 04019028, 2019.

[8] H. W. Ying, Z. H. Chu, B. H. Li, and X. W. Liu, "Study on calculation method of retaining structure with double-row piles and its application," Rock and Soil Mechanics, vol. 28, no. 6, pp. 1145-1150, 2007.

[9] Z. S. Jin and D. Wei, "Discussion on application of double row piles files in Wuhan area," Resources Environment \& Engineering, vol. 24, no. 2, pp. 141-143, 2010.

[10] Q. K. Nie, J. M. Hu, and G. Wu, "Deformation and earth pressure of a double-row piles retaining structure for deep excavation," Rock and Soil Mechanics, vol. 29, no. 11, pp. 3089-3094, 2008.

[11] H. H. Cui, L. Q. Zhang, and G. J. Zhao, "Numerical simulation of deep foundation pit excavation with double-row piles," Rock and Soil Mechanics, vol. 27, no. 4, pp. 662-666, 2006.

[12] Q. S. Liu and J. J. Fu, "Research on model and parameters of double-row piles based on effect of pile-soil contact," Rock and Soil Mechanics, vol. 32, no. 2, pp. 481-486, 2011.

[13] B. Bai, Q. K. Nie, G. Wu, and Z. Q. Su, “A calculation model for double-row-pile retaining structures in deep foundation pit," Journal of Building Structures, vol. 31, no. 8, pp. 118-124, 2010.

[14] P. Huang, H. H. Mo, and J. S. Chen, "Theoritical analysis of double-row piles retaining structure deflection," Chinese Journal of Rock Mechanics and Engineering, vol. 28, no. 2, pp. 3870-3875, 2009.

[15] H. Y. Shi and X. N. Gong, "Study on the behavior of cantilever double-row piles supporting deep excavation," Industrial Construction, vol. 39, no. 10, pp. 67-71, 2009.

[16] F. Wang, Y. W. Liu, J. J. Liang, and J. B. Su, "Research of deformation and earth pressure of tensile anchor double-row piles retaining structure for deep excavation," Building Science, vol. 32, no. 5, pp. 113-119, 2016.

[17] Y. Sun, "Research on calculation method of double-row antisliding structure under sliding surface," Rock and Soil Mechanics, vol. 30, no. 10, pp. 2971-2984, 2009.

[18] X. H. Wang, L. Z. Xie, and M. Zhang, "Numerical simulation and characteristic of a double-row piles retaining structure for deep excavation," Journal of Central South University (Science and Technology), vol. 45, no. 2, pp. 596-602, 2014.

[19] S. Q. Cai, Y. Q. Zhao, and S. M. Wu, "FEM analysis of the deep pit excavation with retaining structure of the double piles in soft clay," Journal of Zhejiang University (Science and Technology), vol. 31, no. 4, pp. 442-448, 1997.

[20] G. Zheng, X. Li, and X. F. Gao, "Analysis of double-row piles in consideration of the pile-soil interaction," Journal of Building Structure, vol. 25, no. 1, pp. 99-106, 2004.

[21] C. Q. Liu, X. Li, and Y. P. Zhang, "Shaking table test and analysis of double row pile retaining structure," China Civil Engineering Journal, vol. 46, no. 2, pp. 190-195, 2013.

[22] X. C. Li, Y. M. Men, T. Zhang, H. J. Liu, and J. P. Yan, "Experimental study on failure modes for anti-slide piles with a single anchor," Chinese Journal of Geotechnical Engineering, vol. 33, no. 5, pp. 803-807, 2011.

[23] A. T. C. Goh, K. S. Wong, C. I. Teh, D. Wen, and D. Wen, "Pile response adjacent to braced excavation," Journal of Geotechnical and Geoenvironmental Engineering, vol. 129, no. 4, pp. 383-386, 2003.

[24] Y. J. Zhou, A. J. Yao, H. B. Li, and X. Zheng, "Correction of earth pressure and analysis of deformation for double-row piles in foundation excavation in Changchun of China," Advances in Materials Science and Engineering, vol. 2016, Article ID 9818160, 10 pages, 2016. 